Науковий вісник НлтУ України
Scientific Bulletin of UNFU
https://nv.nltu.edu.ua
$\begin{gathered}\text { https://doi.org/10.15421/40280912 } \\ \text { Article received 03.10.2018 p. } \\ \text { Article accepted 25.10.2018 p. } \\ \text { Удк 331.5.024 }\end{gathered}$

Н. Д. Мінчак, І. І. Слімаковська

Дрогобииький державний педагогічний університет ім. Івана Франка, м. Дрогобич, Україна

\title{
ОРГАНІЗАЦІЙНА КУЛЬТУРА ПІДПРИЄМСТВА ЯК СКЛАДНИК ЕФЕКТИВНОГО УПРАВЛІННЯ
}

Досліджено особливості формування організаційної культури. Обгрунтовано вплив організаційної культури на систему управління підприємством. З'ясовано, що організаційна культура перебуває у нерозривному зв'язку з основними елементами менеджменту та здійснює вплив на них. Визначено сутність організаційної культури як рівня організаційної структури управління підприємством. Розглянуто наукові підходи до формування організаційної культури підприємства. Проаналізовано наукові дослідження і публікації щодо ефективності розвитку організаційної культури підприємства. Визначено основні чинники, що впливають на формування організаційної культури підприємства. Запропоновано шляхи удосконалення формування організаційної культури підприємства. Досліджено внутрішні чинники, що впливають на формування організаційної культури. Обгрунтовано поділ чинників на групи за характером впливу на організаційну культуру. Виокремлено зовнішні та внутрішні фактори впливу на організаційну культуру підприємства. Доведено, що формування організаційної культури залежить від середовища, в якому працює підприємство. Розглянуто кодекс корпоративної поведінки. З'ясовано, що під час формування організаційної культури одночасно з цінностями підприємства потрібно враховувати і цінності працівників. Розглянуто роль керівника у процесі формування організаційної культури підприємства. Доведено, що на рівень організаційної культури впливають умови праці. Виокремлено основні фактори забезпечення прояву організаційної культури у зовнішньому середовищі.

Ключові слова: персонал; розвиток; чинники; управлінські рішення; робітники; формування; середовище; внутрішні і зовнішні чинники.

Вступ. Важливою умовою ефективного розвитку сучасного підприємства $є$ пошук результативних методів управлінського впливу на персонал. Одним із важливих інструментів такого впливу є формування та розвиток організаційної культури, про що свідчать успіхи підприємств різних країн світу, які декларують основні норми, принципи та правила організаційної культури, визнаючи ії ключовим фактором розвитку та конкурентоспроможності. В Україні організаційна культура найчастіше залишається поза увагою керівників сучасних підприємств.

Фактично немає фахівців 3 питань формування та розвитку організаційної культури, не здійснюють їх підготовку, бракує механізмів розповсюдження передового досвіду у цій сфері. Один з найменш витратних i водночас достатньо ефективних інструментів управлінського впливу використовують на дуже низькому рівні. Впровадження та застосування на сучасних підприємствах ефективних систем організаційної культури дасть змогу вирішувати наявні проблеми управління персоналом підприємства та приймати обгрунтовані управлінські рішення. Організаційна культура впливає не тільки на персонал, а й на підприємство загалом. Висока організаційна культура визначає поведінку робітни- ків, дає робітникам відчуття мети, стратегії ії досягнення, філософії та спонукає їх добре ставитись до свого підприємства, надає впевненості в кінцевому результаті.

Аналіз останніх досліджень і публікацій. Проблемам формування, оцінювання та розвитку організаційної культури значну увагу приділено у працях вітчизняних і зарубіжних науковців, таких як: Т. Е. Діл, А. А. Кеннеді, Р. С. Геллегер, Б. Карлоф, М. Томпсон Кевин, О. С. Виханский, А. І. Наумов, К. С. Камерон, Р. І. Куінн, Г. Хофштеде, В. А. Спивак, А. Е. Воронкова, І. О. Тивончук, М. М. Баб'як, Е. Н. Коренєв, І. В. Мажура, О. Є. Кузьмін, В. І. Павлов, Н. І. Чухрай, Т. В. Ландіна, І. В. Алєксєєв, Г. Л. Хаєт та ін. У дослідженнях цих авторів розкрито сутність організаційної культури, підходи до оцінювання, фактори впливу на організаційну культуру (ї особливості), досліджено окремі складники організаційної культури тощо.

Отже, метою роботи є дослідити сучасні підходи до формування організаційної культури та іiї роль в ефективному управління підприємством.

Викладення основного матеріалу. В умовах посилення конкуренції та підвищення ефективності ведення підприємницької діяльності зростає зацікавленість менеджерів до організаційної культури та основних чин-

\section{Інформація про авторів:}

Мінчак Нінель Джемалівна, канд. екон. наук, ст. викладач, кафедра економіки та менеджменту.

Email: rinaemerald2017@gmail.com

Слімаковська Ірина Ігорівна, магістрант, кафедра економіки та менеджменту. Email: Slimakovska.Iryna@gmail.com

Цитування за ДСТУ: Мінчак Н. Д., Слімаковська І. І. Організаційна культура підприємства як складник ефективного управління. Науковий вісник НЛТУ України. Серія Економічна. 2018, т. 28, № 9. С. 61-64

Citation APA: Minchak, N. J., \& Slimakovska, I. I. (2018). Organizational culture of the enterprise as a part of effective management. Scientific Bulletin of UNFU, 28(9), 61-64. https://doi.org/10.15421/40280912 
ників, що здатні здійснювати вплив на неї. Необхідність дослідження цих факторів обгрунтовується іï впливом на систему управління підприємством. Організаційна культура перебуває у нерозривному зв'язку із основними елементами менеджменту та здійснює вплив на них. Тому, можна стверджувати, що рівень організаційної культури залежить від складників системи управління. Організаційна культура здійснює вагомий вплив на систему управління і водночас залежить від неї. Кожен елемент організаційної культури змінюється та розвивається під впливом багатьох факторів, які здатні забезпечити достатньо високий рівень організаційної культури. Організаційна культура виступає як найважливіший чинник, що впливає на організаційну поведінку i корпоративний розвиток. Одним із найефективніших інструментів управління персоналом підприємства і мотивації його діяльності є організаційна культура.

Організаційна культура - високий рівень організаційної структури управління підприємством та соціального клімату на ньому і вміння керівництва вдосконалювати їх відповідно до стратегічних і тактичних цілей (Levitckaia, 2018). Українські підприємства усвідомлюють необхідність формування організаційної культури, але наразі не знають, як саме розвивати організаційну культуру, як економічно оцінити її ефективність, як організаційна культура впливає на основні показники діяльності підприємства. Вплив організаційної культури на сьогодні досить важко визначити, оскільки більшість підприємств України тільки почала проявляти інтерес до їі впровадження. Деякі підприємці стверджують, що використання культури деякою мірою може навіть зашкодити, оскільки дуже важко побороти український менталітет. Проте однозначно стверджувати так недоцільно, оскільки більшість підприємств ще не застосовувала організаційної культури. Важко відповісти, чи використовуватиметься організаційна культура у нас, хоча чимало західних технологій вже впроваджують та згодом закріплюють в Україні. Ефективний розвиток організаційної культури на підприємстві можливий за умови застосування налагодженого процесу iї формування (Turovetc \& Rodionova, 2004). Тому на підставі опрацювання літературних джерел та практики діяльності підприємств процес формування організаційної культури $\epsilon$ послідовність визначення цінностей організаційної культури, формування поведінки працівників, здійснення ефективної діяльності підприємства та забезпечення інтересів усіх учасників діяльності підприємства. Зважаючи на потребу постійного удосконалення організаційної культури, доцільно процес формування організаційної культури підприємства постійно удосконалювати та підтримувати, що дасть змогу менеджерам оцінити вплив культури на показники діяльності підприємства та зробити висновки про значний вплив цієї категорії на діяльність, що своєю чергою, доведе необхідність застосування норм організаційної культури.

Формування організаційної культури залежить від середовища, в якому працює підприємство, та від внутрішніх чинників. До внутрішніх факторів відносять місію і цілі діяльності підприємства, їі стратегію, характер і зміст роботи, кваліфікацію, загальний рівень розвитку працівників, особистість керівника в організації (Persikova, 2002). Але цей перелік $є$ значно ширшим i доцільно буде розглянути всі внутрішні складники, що здійснюють вплив на організаційну культуру для оцінювання рівня організаційної культури. До зовнішніх факторів відносять ділових партнерів, конкурентів, органи державної влади, систему законодавства, громадські організації, економічні відносини у державі, міжнародні відносини, науково-технічний прогрес та ін. (Chernykh, 2018). Вплив як внутрішніх, так і зовнішніх чинників $є$ дуже вагомим. Щодо внутрішніх чинників, то їх вплив залежить безпосередньо від учасників підприємницької діяльності. Дослідження внутрішніх чинників за ознакою характеру впливу на організаційну культуру дасть змогу оптимізувати способи впливу цих факторів на рівень організаційної культури та економічні показники діяльності. За характером впливу на організаційну культуру чинники треба розділити на такі групи:

- фактори документального забезпечення організаційної культури;

- фактори управлінського впливу;

- ціннісні фактори;

- фактори забезпечення умовами і засобами праці;

- фактори соціального розвитку;

- фактори інтелектуального розвитку;

- фінансово-економічні фактори (Khaiet, et al., 2003).

Організаційна культура повинна забезпечувати порядок у роботі підприємства, а тому доцільно передусім розглянути нормативне забезпечення організаційної культури на підприємстві. Одним із таких факторів є кодекс корпоративної поведінки: розроблення на підприємствах внутрішніх правил і норм поведінки, заборон, пояснень, інструкцій, положень, пам'яток, брошур, що стосуються нормування діяльності працівників підприємства. Кодекс корпоративної поведінки дає змогу ефективно розподіляти обов'язки між працівниками та нести юридичну, інформаційну, соціальну, корпоративну та фінансово-економічну відповідальність. Проте потрібно пам'ятати, що впровадження правил може викликати протест. А тому необхідно мотивувати працівників до дотримання цих правил. Для працівників потрібно визначити кількість правил, обов'язкових до виконання, залежно від виду здійснюваної роботи. Створення корпоративних правил та чітке їх виконання дасть змогу:

- забезпечити безпеку підприємства;

- формалізувати відносини між працівниками, між працівниками та менеджерами;

• попередити або розв'язати конфліктні ситуації;

- привабити клієнтів;

- забезпечити прийняття ефективних рішень, які будуть базуватись не тільки на інтуїції менеджера (Chernykh, 2018).

Отже, першим і вагомим чинником формування організаційної культури $є$ встановлення та дотримання правил. Існування цих правил дасть змогу підприємству:

- ефективно здійснювати управління персоналом та полегшить цей процес;

- забезпечити економію часу - кожен знатиме свої обов'язки, що, як і коли потрібно робити;

- впливати на працівників, використовуючи невстановлені правила;

- впливати на рівень організаційної культури.

Розроблення кодексів поведінки повинне базуватись на етичних нормах і правилах, враховувати сферу діяльності підприємства, його особливості та забезпечити запобігання виникнення суперечливих ситуацій. 
Одночасно із цінностями підприємства під час формування організаційної культури потрібно враховувати i цінності працівників, оскільки саме працівники найчіткіше виражають той чи інший тип організаційної культури. Працівники повинні самостійно і чітко усвідомлювати вплив організаційної культури. На таких підприємствах помітно підвищується продуктивність праці, якість виготовленої продукції, зменшується плинність кадрів, підвищується рівень саморозвитку, імідж, репутація підприємства, покращуються взаємини між самими працівниками, зростає економічна ефективність діяльності підприємства. Від індивідуальних цінностей залежить процес підбору персоналу в організації. Формування цінностей, які $є$ основою організаційної культури працівника, залежить від цінностей суспільства, сім'ї та підприємства, на якому працівник реалізовує свої можливості.

Вагомий вплив на організаційну культуру, iї формування, донесення до працівників - відіграє керівництво Тут треба виділити такий фактор впливу, як фактор управлінського впливу, оскільки керівництво підприємства визначає основні цінності та принципи організаційної культури. Керівники повинні поважати своїх підлеглих, вміти їх слухати, піклуватись про них, оскільки це сприяє розвитку гармонійних міжособистісних стосунків у колективі та відчуття одного цілого 3 компанією.

На рівень організаційної культури також впливає і забезпечення відповідними умовами праці. Наявність необхідного технічного укомплектовання робочого місця, забезпечення побутових цілей, постійне покращення умов праці (забезпечення сучасними технічними засобами), забезпечення уніформою 3 корпоративною символікою - все це $\epsilon$ виявленням турботи із сторони керівництва про своїх працівників. А отже, забезпечуе приклад виявлення і дотримання норм організаційної культури.

Фактори забезпечення прояву організаційної культури у зовнішньому середовищі. Найменування підприємства, формування логотипу та торгового знаку, емблеми, гасла, місії, створення образу фірми (історія організації, іiі герої, міфи, легенди, традиції та ритуали, фірмовий стиль одягу) - все це $\epsilon$ зовнішніми проявами організаційної культури, найбільш чітко візуально до- носять до зовнішніх користувачів інформацію про організаційну культуру. Корпоративна символіка (форма, одяг, буклети, ручки, брошури та ін.) є виявом турботи підприємства про своїх працівників і в той же час дає змогу легко розпізнавати організаційну культуру та стандартизує іiі. Впровадження та дотримання принципів організаційної культури дасть змогу зробити іiї могутнім інструментом управління персоналом, забезпечить цілісність організації, створить сприятливі умови для управління підприємством, сприятиме стабільному розвитку організаційної культури та виконанню іiї основних функцій.

Висновки. Отже, в умовах ринкової економіки організаційна культура $є$ фактором ефективного управління підприємством. Вона покликана сприяти найефективнішому використанню людського фактору для досягнення мети підприємства і особистої мети кожного працівника. Вирішення управлінських проблем стає можливим тільки використовуючи на практиці науково розроблені концепції, які передбачають формування і розвиток організаційної культури. Організаційна культура як науково-практичний напрямок $є$ невід'ємною складовою частиною загальної науки управління. Усі наукові напрямки переслідують кінцеву мету підприємства. Отже, організаційна культура загалом впливає на розвиток підприємства. Якість управління залежить від того на якому рівні та як були використані окремі інструменти організаційної культури.

\section{Перелік використаних джерел}

Chernykh, E. A. (2018). Korporativnaia i organizatcionnaia kulturasinonimy ili raznye poniatiia. Retrieved from: http://www.corpculture.ru/content/korporativnaya-i-organizatsionnaya-kultura-sinonimy-ili-raznye-ponyatiya. [In Russian].

Khaiet, H. L. (Ed.), Yeskov, O. L., Khaiet, L. H., Kovalevskyi, S. V., \& Medvedieva, O. A. (2003). Korporatyvna kultura. Kyiv: Tsentr navchalnoi literatury, $403 \mathrm{p}$. [In Ukrainian].

Levitckaia, P. V. (2018). Korporativnye tcennosti v usloviiakh informatcionnogo obshhestva. Retrieved from: http://www.promgups.ru/publisher/txt3/more.php? more=14. [In Russian].

Persikova, T. N. (2002). Mezhkulturnaia kommunikatciia i korporativnaia kultura. Moscow: Logos, 224 p. [In Russian].

Turovetc, O. G., \& Rodionova, V. N. (2004). Teoriia organizatcii. Moscow: INFRA-M, 128 p. [In Russian].

Н. Д. Минчак, И. И. Слимаковская Дрогобычский государственный педагогический университет им. Ивана Франко, г. Дрогобыч, Украина

\section{ОРГАНИЗАЦИОННАЯ КУЛЬТУРА ПРЕДПРИЯТИЯ КАК} СОСТАВЛЯЮЩАЯ ЭФФЕКТИВНОГО УПРАВЛЕНИЯ

Исследованы особенности формирования организационной культуры. Обосновано влияние организационной культуры на систему управления предприятием. Определено, что организационная культура есть в неразрывной связи с основными элементами менеджмента и осуществляет влияние на них. Определена сущность организационной культуры как уровня организационной структуры управления предприятием. Рассмотрены научные подходы к формированию организационной культуры предприятия. Проведён анализ научных исследований и публикаций по эффективности развития организационной культуры предприятия. Определены основные факторы, которые влияют на формирование организационной культуры предприятия. Предложены пути усовершенствования формирования организационной культуры предприятия. Исследованы внутренние факторы, влияющие на формирование организационной культуры. Обосновано разделение факторов на группы по характеру влияния на организационную культуру. Выделены внешние и внутренние факторы влияния на организационную культуру предприятия. Доказано, что формирование организационной культуры зависит от среды, в которой работает предприятие. Рассмотрен кодекс корпоративного поведения. Выяснено, что при формировании организационной культуры одновременно с ценностями предприятия следует учитывать и ценности рабочих. Рассмотрена роль руководителя в процессе формирования организационной культуры предприятия. Доказано, что на уровень организационной культуры влияют условия труда. Выделены основные факторы обеспечения проявления организационной культуры во внешней среде.

Ключевые слова: персонал; развитие; факторы; управленческие решения; работники; формирование; среда; внутренние и внешние факторы. 
N. J. Minchak, I. I. Slimakovska

ORGANIZATIONAL CULTURE OF THE ENTERPRISE AS A PART OF EFFECTIVE MANAGEMENT

The peculiarities of organizational culture formation are explored. The influence of organizational culture on the enterprise management system is grounded. Organizational culture is found to be in close connection with the basic elements of management and influencing them. The essence of organizational culture as the level of organizational structure of enterprise management is determined. The scientific approaches concerning formation of organizational culture of the enterprise are considered. The analysis of scientific researches and publications concerning the effectiveness of the development of organizational culture of the enterprise was performed. The main factors influencing the formation of organizational culture of the enterprise are determined. The ways of improvement of formation of organizational culture of the enterprise are offered. The internal factors that influence the formation of organizational culture are investigated. The division of factors into groups according to the nature of influence on organizational culture is grounded. The external and internal factors influencing the organizational culture of the enterprise are distinguished. It is proved that the formation of organizational culture depends on the environment in which the company operates. The Code of Corporate Conduct is considered. It is found out that when forming an organizational culture simultaneously with the values of the enterprise the values of employees should be taken into account. The role of the head in the process of forming the organizational culture of the enterprise is considered. Working conditions are proved to influence the level of organizational culture. The main factors of ensuring the manifestation of organizational culture in the external environment are highlighted.

Keywords: personnel; development; factors; managerial decisions; workers; formation; environment; internal and external factors. 